\title{
Clinical Trial Suspension
}

National Cancer Institute

\section{Source}

National Cancer Institute. Clinical Trial Suspension. NCI Thesaurus. Code C156631.

An interruption in some or all clinical trial activities. 